\title{
PEMANENAN AIR HUJAN SEBAGAI PENYEDIAAN AIR BERSIH PADA ERA NEW NORMAL DI KELURAHAN SUSUNAN BARU
}

\author{
Fera Lestari'1), Try Susanto'), Kastamto') \\ 1)Program Studi Teknik Sipil, Fakultas Teknik dan Ilmu Komputer, Universitas Teknokrat Indonesia, \\ Bandar Lampung, Lampung, Indonesia \\ 2)Program Studi Teknik Komputer, Fakultas Teknik dan IImu Komputer, Universitas Teknokrat Indonesia, \\ Bandar Lampung, Lampung, Indonesia \\ Corresponding author : Fera Lesdtari \\ E-mail : fera_lestari@teknokrat.ac.id,
}

\section{Diterima 05 April 2021, Direvisi 18 April 2021, Disetujui 19 April 2021}

\begin{abstract}
ABSTRAK
Susunan Baru merupakan kelurahan yang berada di kecamatan Tanjung Karang Barat, Kota Bandar Lampung, Lampung. Kelurahan Susunan Baru tidak jarang mendapatkan bantuan air bersih berupa penyaluran air bersih. Hal ini dilakukan dalam rangka merespon sulitnya akses air bersih diwilayah tersebut dikarenakan kondisi tanah berbatu dan berada didataran tinggi. Sudah sejak Kelurahan Susunan Baru kesulitan dalam mendapatkan air bersih apabila musim kering tiba. Kegiatan Pengabdian Kepada Masyarakat diharapkan dapat memberikan pengetahuan mengenai cara mendapatkan alternatif sumber air bersih dari air hujan dan meningkatkan pemahaman pentingnya memanfaatkan air hujan sebagai sumber air bersih untuk kebutuhan mandi dan mencuci serta diharapkan dapat memberikan keterampilan baru bagi masyarakat dalam membuat teknologi pemanenan air hujan yang dapat menjadi sumber air bersih untuk pemenuhan kebutuhan air bersih di tingkat rumah tangga. Alat panen hujan yang telah dibuat berfungsi dengan baik karena pada saat hujan turun air hujan masuk kedalam alat panen hujan dan ditampung. Dengan perhitungan volume air hujan dengan berbagai asumsi didapatkan air yang dapat ditampung selama seminggu adalah sebanyak 1350 liter. Jika dalam satu hari air yang digunakan untuk mencuci tangan mencapai 60 Liter. Maka air yang tertampung mampu memenuhi kebutuhan mencuci tangan selama 22 hari. Dari hasil Pengabdian yang dilakukan diketahui bahwa Kelurahan dapat menghemat penggunaan air untuk cuci tangan selama 22 hari dengan terisinya alat panen hujan, terlebih lagi jika hujan yang terjadi lebih dari 3 kali seminggu. Adanya tampungan dari air hujan menambah sumber air baru yang dapat dimanfaatkan untuk kegiatan seharihari dan menjadi suatu alternatif dalam penyediaan air bersih
\end{abstract}

Kata kunci: air hujan; pemanenan air hujan; sumber air bersih.

\begin{abstract}
Susunan Baru is a village located in Tanjung Karang Barat sub-district, Bandar Lampung City, Lampung. Kelurahan Susunan Baru often receives clean water assistance in the form of clean water distribution. This is done in response to the difficulty of access to clean water in the area due to the rocky soil conditions and highlands. Already, Susunan Baru Village has had difficulty getting clean water when the dry season arrives. Community Service Activities are expected to provide knowledge about how to obtain alternative sources of clean water from rainwater and increase understanding of the importance of utilizing rain water as a source of clean water for bathing and washing needs and are expected to provide new skills for the community in making rainwater harvesting technology that can become a source of clean water to meet the needs of clean water at the household level. The rain harvesting tool that has been made functions well because when it rains, the rainwater enters the rain harvesting tool and is collected. By calculating the volume of rainwater with various assumptions, it is found that the water that can be stored for a week is as much as 1350 liters. If in one day the water used to wash hands reaches 60 liters. Then the collected water is able to meet the needs of washing hands for 22 days. From the results of the Community Service, it is known that the Kelurahan can save water use for washing hands for 22 days by filling up rain harvesting tools, especially if it rains more than 3 times a week. The existence of storage from rainwater adds new water sources that can be used for daily activities and becomes an alternative in the provision of clean water
\end{abstract}

Keywords: rain water; rain water harvesting;source of clean water. 


\section{PENDAHULUAN}

Pada tahun 2015 PBB mengeluarkan blue print yang tujuannya adalah mewujudkan pembangunan yang berkelanjutan atau dikenal dengan Sustainable Development Goals (SDGs). Hal ini memunculkan komitmen yang menyatakan bahwa masyarakat global kedepan akan menghadapi tantangan berkaitan dengan kemiskinan, ketidaksamaan, masalah iklim, degradasi lingkungan, kesejahteraan, perdamaian, serta masalah keadilan. (Murniningtyas \& Endah, 2018)

Berkaitan dengan hal tersebut perlu adanya pemecahan masalah yang muncul terkait dengan adanya pemenuhan kebutuhan air bersih dan sanitasi yang layak sebagai suatu tantangan yang akan dihadapi kedepannya. Hal ini perlu menjadi perhatian dikarenakan degradasi lingkungan merupakan salah satu elemen SDGs sehingga dalam menjawab masalah tersebut panel tingkat tinggi PBB berkaitan dengan SDGs menyepekati untuk pemenuhan akses air minum bersih dan sanitasi wajib dicapai masyarakat dunia pada 2030.

Indonesia merupakan salah satu dari 193 negara yang turut ikut dalam menyepakati komitmen SDGs yang dikeluarkan oleh PBB. Bentuk dari implementasi komitmen tersebut terlihat dari adanya keterkaitan komitmen SDGs dalam Nawacita Pemerintah Joko Widodo dan Jusuf Kalla. Tidak hanya itu, perwujudan komitmen ini juga dituangkan ke dalam Rencana Pembangunan Jangka Menengah Nasional (RPJMN) 2015-2019 yang ditandai dengan adanya suatu program berupa program agenda nasional 100\% Akses Universal Air Minum dan Sanitasi ditahun 2019 (Badan Perencanaan Pembangunan Nasional, 2014). Gambaran dari kondisi saat ini mengenai akses layanan air layak minum di Indonesia baru mencapai $72 \%$. Angka tersenbut menunjukkan masih diperlukan kerja nyata dari semua stake holder untuk menutupi kekurangan sebesar $28 \%$.

Dalam UU No. 23 tentang Pemerintah Daerah, Pasal 12 Ayat 1 disebutkan bahwa pelayanan air minum dan sanitasi merupakan kewenangan daerah dan menjadi urusan wajib yang berkaitan dengan pelayanan dasar. Hal tersebut menunjukkan adanya kepenitingan dari pemerintah pusat untuk mendorong pemerintah daerah guna memprioritaskan program serta anggaran daerah untuk pembangunan layanan infrastruktur dasar tersebut. Pembangunan SPAM Bandar Lampung dengan kapasitas 750 liter/detik yang akan melayani 300 ribu penduduk di Kota Bandar Lampung yang saat ini sedang dalam proses konstruksi dan diperkirakan beroperasi pada 2021. (Dewanto, 2019)

Air telah menjadi kebutuhan vital dalam kehidupan manusia dan ketersediaannya mutlak untuk menunjang keberlangsungan hidup manusia dalam melakukan aktivitasnya di kehidupan bermasyarakat. (Mugagga \& Nabaasa, 2016)

Dalam memenihi kebutuhan air tersebut untuk melaksanakan kegiatannya sehari-hari masyarakat dengan pengetahuan, kebiasaan, dan budaya yang diwariskan secara turun menurun memanfaatkan sumber air di wilayahnya. Dalam mengelola sumber daya tersebut masyarakat hidup secara berdampingan dengan harmonis dengan alam disekitarnya.

Dalam pemenuhan kebutuhan air maka akan ada sumber- sumber yang digunakan untuk mendapatkan air yang selanjutnya disebut atau dikenal sebagai Sumber daya air. Secara umum sumber daya air dapat didefinisikan sebagai sumber daya berupa air yang berguna dan atau berpotensi menyediakan kebutuhan air bagi manusia. Seperti yang telah diketahui, air merupakan sumber kehidupan. Kegunaan air meliputi penggunaan dibidang pertanian, industri, rumah tangga, rekreasi, dan aktivitas lingkungan. $\mathrm{Hal}$ ini menunjukan dengan sangat jelas bahwa setiap manusia yang hidup di planet bumi ini adalah manusia yang membutuhkan air tawar.

Sebesar $97 \%$ air di bumi merupakan air asin dan sisanya sebesar $3 \%$ merupakan air tawar dimana lebih dari dua per tiga bagiannya berada dalam bentuk es di glasier dan es kutub. Sumber air tawar yang tidak membeku dapat ditemukan terutama di dalam tanah berupa air tanah, dan hanya sebagian kecil berada di atas permukaan tanah dan di udara.

Sumber air tawar merupakan sumber daya yang terbarukan. Meskipun pada kenyataanya saat ini penyediaan air bersih terus berkurang. Saat ini permintaan air sudah dapat dikatakan melebihi penyediaan. Baik di beberapa belahan dunia maupun diseluruh belahan dunia populasi terus meningkat. Meningkatnya populasi manusia di planet ini berpotensi menimbulkan peningkatan permintaan terhadap air bersih. Perhatian terhadap kepentingan global dalam mempertahankan air untuk pelayanan ekosistem telah bermunculan. Hal ini dapat dilihat sejak dunia telah kehilangan lebih dari setengah lahan basah bersama dengan nilai pelayanan ekosistemnya. Ekosistem air tawar yang tinggi biodiversitasnya saat ini terus berkurang, laju penurunannya lebih cepat 
dibandingkan dengan ekosistem yang ada di laut ataupun ekosistem yang ada di darat.

Sebanyak kurang lebih $15 \%$ penggunaan air yang digunakan di seluruh dunia merupakan penggunaan air oleh rumah tangga. Penggunaan air ini berkaitan dengan kegiatan rumah tangga meliputi penggunaan air untuk air minum, mandi, memasak, sanitasi, dan berkebun. Diperkirakan kebutuhan minimum air yang dalam satu rumah tangga adalah sekitar 50 liter per individu per hari. Kebutuhan tersebut belum termasuk kebutuhan berkebun. Selayaknya air yang digunakan untuk minum haruslah air yang berkualitas baik sehingga dapat secara langsung dikonsumsi tanpa adanya risiko bahaya yang akan timbul. Hampir diseluruh negara yang masuk kedalam kategori negara berkembang, air yang dipasok untuk kebutuhan rumah tangga dan kebutuhan industri merupakan air minum standar meski terdapat proporsi yang sangat kecil dimana air yang disesiakan dapat digunakan untuk dikonsumsi langsung atau pengolahan makanan.

Menurut World Business Council for Sustainable Development krisis air merupakan kondisi atau situasi dimana tidak ada cukup air untuk memenuhi semua kebutuhan, baik kebutuhan air untuk pertanian, industri, atau yang lainnya. Mendefinisikan masalah ini dalam bentuk per kapita lebih akan lebih komplek, namun dapat memunculkan asumsi yang lebih baik untuk penggunaan air dan upaya penghematannya. Namun telah diramalkan bahwa ketika ketersediaan air yang dapat diperbarui di bawah 1.700 meter kubik per kapita per tahun, dapat disimpulkan negara tersebut akan mengalami krisis air secara berkelanjutan. Sedangkan jika ketersediaan air dibawah 1.000 meter kubik maka kelangkaan air akan terjadi dan keadaan ini akan berakibat terhambatnya pertumbuhan ekonomi dan kesehatan manusia.

Perserikatan Bangsa-Bangsa atau PBB menyatakan, jumlah penduduk dunia saat ini tercatat sebanyak 7,6 miliar dan akan melonjak menjadi 9,8 miliar pada tahun 2050 . PBB memperkirakan bahwa mulai sekarang hingga 2050, setengah pertumbuhan populasi dunia akan terkonsentrasi di sembilan negara, yakni India, Nigeria, Kongo, Pakistan, Ethiopia, Tanzania, Amerika Serikat, Uganda dan Indonesia. Dimana peningkatan atau pertumbuhan terbesar berada di negara-negara berkembang dimana telah terlebih dahulu berada pada kondisi telah mengalami krisis air.(Pramadiba, 2017)

Peningkatan penduduk tentu saja sejalan dengan peningkatan kebutuhan air dan hal tersebut akan menyebabkan peningkatan permintaan air. Kondisi ini dapat dihindari ataupun diatasi. Dengan melakukan konservasi dan mendaur ulang sumber daya yang sangat penting ini keadaan krisis air dapat terhindarkan.

Kebutuhan akan pangan dan kebutuhan akan air oleh manusia akan terus ada karena merupakan kebutuhan dasar manusia yang harus dipenuhi untuk mempertahankan hidup. Namun kondisi global yang terjadi pada tahun 2002 menunjukan bahwa dari sepuluh orang, terdapat lima orang diantaranya telah memiliki akses ke suplai air berpipa di rumah, sedangkan tiga orang lainnya memiliki tipe suplai air lainnya seperti mata air terlindung atau pipa air publik, dan dua orang lainnya tidak memiliki akses air bersih sama sekali. Ditambah lagi dari empat dari sepuluh orang tersebut hidup tanpa sanitasi yang berarti.

Dalam Earth Summit 2002, para pemerintahan dari berbagai negara menyetujui Plan of Action yang bertujuan untuk mengurangi hingga setengah dari jumlah rakyat yang tidak mampu untuk mendapatkan air minum yang aman pada tahun 2015. (Murniningtyas \& Endah, 2018). Global Water Supply and Sanitation Assessment 2000 Report (GWSSAR) menjelaskan bahwa setiap orang harus mendapatkan akses sebesar 20 liter per harinya dari sumber sejauh maksimal satu kilometer dari tempat tinggalnya.

Plan of action juga menyepakati mengenai pengurangan setengah jumlah yang tidak memiliki akses ke sanitasi dasar. GWSSAR mendefinisikan sanitasi dasar sebagai suatu sistem pembuangan pribadi atau komunal namun bukan milik umum yang memisahkan limbah dari kontak dengan manusia.

Selanjutnya diprediksi pada tahun 2025, akan terjadi kelangkaan air, terlebih kondisi kelangkaan air akan lebih terlihat di negara miskin di mana sumber daya air yang terbatas dan perkembangan populasi meningkat, seperti di Afrika, Timur Tengah, dan beberapa bagian di Asia. Diprediksi pada tahun 2025, area urbanisasi yang besar akan membutuhkan banyak infrastruktur baru untuk menyediakan air yang aman dan sanitasi yang pantas. Hal ini diperkirakan akan menimbulkan konflik dengan pengguna air di pertanian, yang saat ini menggunakan sebagian besar air yang digunakan oleh seluruh manusia. Sejak tahun 1990 ada sekitar kurang lebih 1,6 miliar orang saat ini sudah mendapatkan akses sumber air yang aman. Rasio jumlah masyarakat di negara-negara yang sedang berkembang dengan akses air yang aman diramalkan akan meningkat dari yang semula hanya sebedar 30 
persen hingga menjadi 71 persen pada tahun 1990, 79 persen pada tahun 2000, dan 84 persen pada tahun 2004. Kecenderungan ini diperkirakan akan berlanjut. (Badan Pusat Statistik, 2015)

Keadaan pandemi Covid 19 mensyaratkan protokol kesehatan termasuk di lingkup yang terkecil yaitu Keluarga. Salah satu protokol kesehatan yang disyaratkan adalah mencuci tangan dengan sabun. Peneliti di Inggris menyarankan agar setiap orang mencuci tangan setidaknya enam sampai 10 kali sehari sebagai salah satu cara untuk mencegah penularan virus corona (Afifah, 2020)

Dalam kondisi pandemi Covid 19 ini setiap orang melakukan cuci tangan dengan frekuensi yang lebih sering hinga 6- 10 kali. Jika diasumsikan kebutuhan air untuk mencuci tangan dalam satu kali cuci tangan adalah 1 liter maka akan ada peningkatan kebutuhan air untuk memenuhi aktivitas mencuci tangan. Dengan jumlah penduduk 1,3 juta di bandar lampung ini maka diperkirakan dibutuhkan air bersih 5 m3/detik untuk mencuci tangan.

Tuhan telah memberikan anugrah yang besar bagi umat manusia melalui hujan yang diturunkan ke bumi. Turunnya hujan menjadi sangat berarti saat musim kering dan dianggap musibah saat menimbulkan banjir di musim penghujan. (Maryono, 2020)Selama ini masih banyak anggapan bahwa hujan hanyalah suatu peristiwa alam yang terlewat begitu saja, padahal jika dikelola dengan baik, air hujan dapat menjadi sumber yang bermanfaat bagi masyarakat, khususnya yang kesulitan terhadap akses air bersih. Air hujan tersebut dapat membantu kegiatan masyarakat seperti memasak, mencuci, mandi. Masyarakat belum sepenuhnya menyadari betapa pentingnya air hujan dalam kehidupan. Pentingnya sanitasi dan air bersih seyogyanya diutamakan dalam kehidupan sehari-hari

$$
\text { Minimnya aloksi dana yang }
$$

disediakan menyebabkan ketidakmampuan dalam menutupi kebutuhan ketersediaan air bersih, sehingga menimbulkan masalah di berbagai daerah. Banjir dan kekeringan sekarang ini sudah menjadi permasalahan yang mendasar, khususnya di berbagai wilayah di Indonesia. Peristiwa alam ini memicu terjadinya kekurangan air bersih di beberapa wilayah. Hal ini kurang lebih juga terjadi karena adanya pengelolaan lingkungan yang kurang baik. Faktor yang ingin ditekankan saat ini adalah faktor pengelolaan air hujan yang kurang memadai. Air hujan merupakan sumber air yang banyak tersedia di alam dan dapat diakses secara gratis (Sitorus et al., 2010). Pengelolaan yang baik dari air hujan tidak hanya akan megatasi permasalahan ketersediaan air di musim kemarau dan kelebihan air di musim hujan, tetapi juga akan meminimalisasi penggunaan dana.

Susunan Baru merupakan kelurahan yang berada di kecamatan Tanjung Karang Barat, Kota Bandar Lampung, Lampung. Kelurahan Susunan Baru tidak jarang mendapatkan bantuan air bersih. Bantuan air bersih berupa penyaluran air bersih tersebut dilakukan dalam rangka merespon sulitnya akses air bersih diwilayah tersebut dikarenakan kondisi tanah berbatu dan berada didataran tinggi. Sudah sejak Kelurahan Susunan Baru kesulitan dalam mendapatkan air bersih apabila musim kering tiba. Meskipun hujan sempat mengguyur Kota Bandar Lampung namun belum mampu mencukupi kebutuhan air bersih. Saat ini warga masih bergantung dengan air sumur bor yang berada di lingkungannya. Sumur bor tersebut dibangun Kelompok masyarakat. (Nidia, 2019)

Dari uraian permasalahn mitra kegiatan ini dapat menjadi solusi permasalahan mitra. Kegiatan penyediaan air bersih melalui pemanenan air hujan ini merupakan sebuah kegiatan pemberian penyuluhan mengenai pentingnya air bersih serta pelatihan pembuatan alat penyaringan dengan memanfaatkan sumber air hujan.

Kegiatan ini berguna untuk memberikan suatu cara yang baru dalam pengadaan air bersih di lingkungan masyarakat yaitu dengan pemanfaatan air hujan secara optimal untuk menghasilkan air bersih dengan biaya yang terjangkau. Suatu kemudahan dalam pengadaan air bersih dapat berpengaruh terhadap terjaganya pola hidup yang bersih, sehat dan terjaga.

\section{METODE}

\section{Waktu dan Lokasi Kegaitan}

Waktu pelaksanaan kegiatan Pengabdian kepada Masyarakat ini dilakukan dari bulan Juli 2020 hingga Januari 2021. Lokasi kegiatan bertempat di Kelurahan Susunan Baru yang beralamat di Jl. Poebian No. 15 Susunan Baru Kecamatan Tanjung Karang Barat, Bandar Lampung Provinsi Lampung

\section{Tahapan Kegiatan}

Kegiatan Pengabdian Kepada Masyarakat ini dibagi menjadi tiga tahap yaitu tahap persiapan, tahap kegiatan serta tahap evaluasi dan monitoring. Tahap persiapan dilakukan sebelum pelaksanaan kegiatan, kegiatan persiapan ini berupa koordinasi kepada lurah setempat, selanjutnya dilakukan peninjauan lokasi untuk alat panen hujan dan keadaan pendukung seperti kondisi atap, ketersediaan talang air serta tempat peletakan alat panen 
hujan. Selain peninjauan lokasi dilakukan juga peninjauan terhadap alat dan bahan yang bisa digunakan serta ketersedian masyarakat dalam pelaksanaan kegiatan. Setelah tahap persiapan dilakukan selanjutnya dilakukan tahap kegiatan yang terdiri dari kegiatan sosialisasi dan kegiatan pembuatan alat panen hujan.Kegiatan pertama dilakukan pada hari kamis 28 Agustus 2021 di aula kelurahan susunan baru. Kegiatan sosialisasi ini dihadiri oleh 21 warga keluarahan susunan baru. Kegiatan sosialisasi yang dihadiri oleh masyarakat susunan baru ini meliputi sosialisasi tentang pemanfaatan air hujan untuk air bersih dan pemanenan air hujan. Pada Sosialisasi tentang pemanfaatan air hujan untuk air bersih, masyarakat akan diingatkan lagi mengenai pentingnya air bersih serta beberapa cara penanggulangan yang dapat diterapkan secara praktis. Selanjutnya dilanjutkan dengan diskusi dan pengenalan teknologi alat panen hujan. Diskusi dan pengenalan alat panen hujan ini dilakukan untuk mengetahui permaslahan yang saat ini terjadi dan potensi apa yang dapat dilakukan kedepannya serta memperkenalkan salah satu bentuk teknologi sederhana yang dapat membantu mengatasi masalah air bersih di wilayah tersebut, dan akan dijelaskan fungsi serta cara kerjanya.

Tahapan kegiatan selanjutnya setelah sosialisasi adalah pembuatan alat panen hujan. Kegiatan ini dilakukan dengan melibatkan masyarakat kelurahan Susunan Baru. Pembuatan alat panen hujan dimulai dengan penentuan lokasi penempatan alat. Alat ditempatkan pada bagian atap yang memiliki talang. Selanjutnya adalah penyiapan alat dan bahan yang dibutuhkan. Bahan yang digunakan antara lain tandon air, pipa PVC 3", Socket, Sambungan Pipa, dan lain-lain. Sedangkan alat yang digunakan antara lain gergaji, bor tangan, palu, dan lain-lain.

Perakitan pipa saluran dari talang menuju tandon air dilakukan oleh mahasiswa Teknik Sipil Universitas Teknokrat Indonesia. Pada lokasi peletakan alat panen hujan belum ada dudukan yang dapat meninggikan letak alat panen hujan. Hal ini dibutuhkan agar air yang tertampung dapat digunakan dengan mengalirkannya ke keran air. Pembuatan dudukan alat panen hujan ini dilakukan oleh masyarakat kelurahan Susunan Baru. Setelah pipa selesai dirakit dan dudukan telah siap maka tandon air diletakan di atas dudukan dan pipa mulai dihubungkan mulai dari ujung talang hingga masuk ke dalam tandon. Tahap akhir adalah mengarahkan ujung pipa saluran air hujan dengan ujung talang agar air hujan yang jatuh tepat masuk kedalam pipa dan akhirnya dapat ditampung kedalam tandon
Tahapan ketiga merupakan tahap evaluasi dan monitoring. Tahapan ini bertujuan untuk mengetahui apakah alat panen hujan yang telah dibuat dan dipasang dapat berfungsi dengan baik dalam menampung air hujan.

\section{HASIL DAN PEMBAHASAN \\ Sosialisasi Pemanenan Air Hujan}

Kegiatan pertama yang dilakukan pada program PkM ini adalah memberikan pemahaman lebih mendalam kepada masyarakat mengenai pemanfaatan penggunaan air hujan dengan cara pemanenan air hujan. Kegiatan peningkatan pemahaman masyarakat mengenai sumber air bersih dan pentingnya melakukan konservasi air dilakukan dengan kegiatan sosialisasi.

Kegiatan sosialisasi diikuti oleh masyarakat kelurahan susunan baru. Gambar 1 menunjukkan proses pelaksanaan kegiatan sosialisasi pemanenan air hujan yang diikuti oleh masyarakat. Sosialisasi dilakukan dengan cara menyampaikan beberapa materi. Materi yang disampaiakan antara lain materi mengenai pentingnya air dalam kehidupan, permasalahan air, pemanfaatan air hujan, contoh pemanfaatan pemanenan air hujan di berbagai daerah dan cara Pemanfaatan air hujan

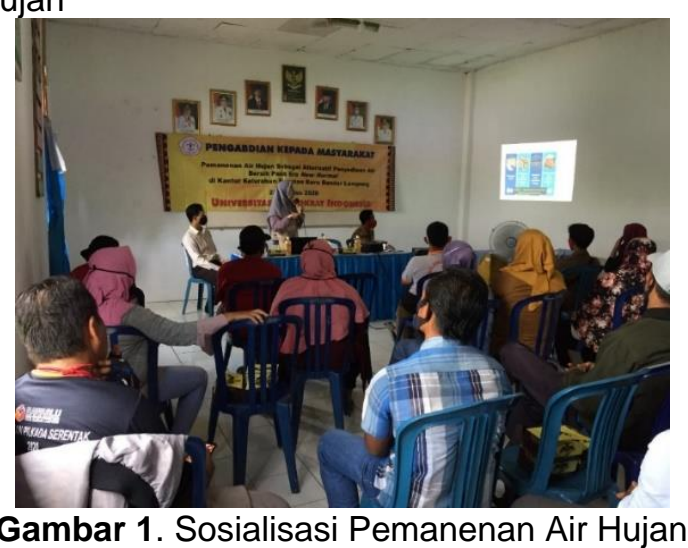

(Sumber :Dokumentasi Pribadi)

Pada pelaksanaan kegiatan sosialisasi mengenai pemanenan air hujan terlihat masyarakat sangat antusias dalam menerima informasi baru mengenai pemanfaatan air hujan sebagai sumber air bersih dan pemanen air hujan. Antusiasme masyarakat terlihat dari banyaknya masyarakat yang hadir dalam kegiatan sosialisasi tersebut dan banyaknya pertanyaan yang diajukan untuk mengetahui lebih dalam terkait pemanfaatan air hujan dan pemanenan air hujan.

\section{Pembuatan Alat Panen Hujan}

Setelah diadakan sosialisasi mengenai pemanfaatan air hujan dan pemanenan air hujan maka dilakukan 
persiapanmengenai rencana pembuatan alat panen hujan yang nantinya alat tersebut akan diletakkan di kantor kelurahan Susunan Baru.

Pembuatan alat panen hujan diawali dengan survei lokasi. Survei lokasi dilakukan dengan cara melakukan pengecekan terhadap atap dan juga talang yang tersedia. Selanjutnya setelah ditentukan lokasi peletakan alat panen hujan dilakukan demobilisasi alat dan bahan. Lokasi alat panen hujan harus berada dibawah talang yang memiliki kondisi baik dimana talang harus berfungsi dengan baik dan bersih dari kotoran. Tujuannya agar air yang jatuh pada atap dan mengalir ke talang dapat dengan mudah mengalir ke alat panen hujan. Selanjutnya setelah menyiapkan lokasi penempatan alat panen hujan adalah penyiapan bahan. Bahan yang yang digunakan dalam pembuatan alat panen hujan diantaranya tandon air, pipa PVC 3", sambungan berupa $\mathrm{T}$ dan elbow. Alat yang digunakan meliputi gergaji untuk memotong pipa, Lem PVC untuk menyambung pipa dan alat-alat lainnya seperti paku, palu dan tang.

Selanjutnya perakitan alat panen hujan dilakukan mulai dari pembersihan dan perbaikan talang, perakitan pipa ujung dari talang, pipa saluran air hujan dan tandon penampung air hujan.

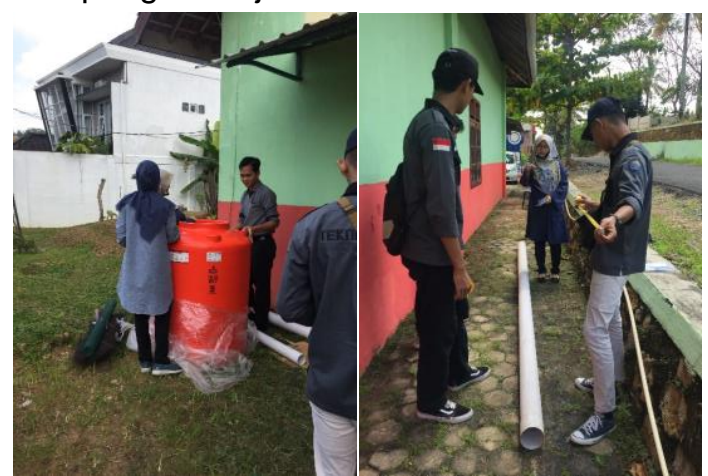

Gambar 2. Penyiapan Alat dan Bahan (Sumber :Dokumentasi Pribadi)

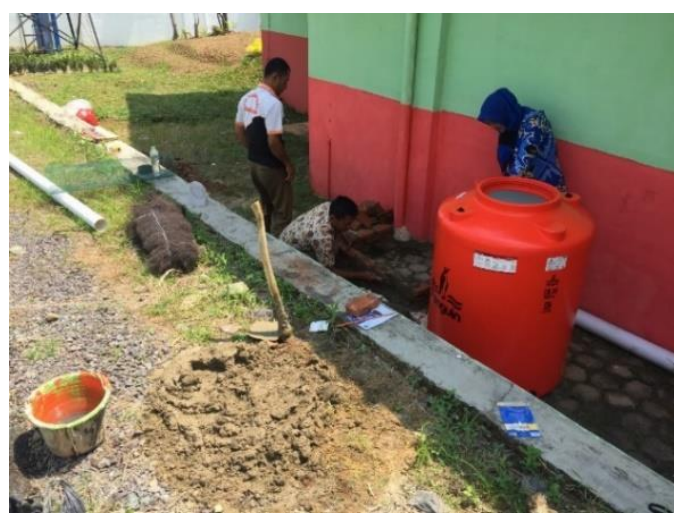

Gambar 3. Penyiapan Alat dan Bahan (Sumber :Dokumentasi Pribadi)

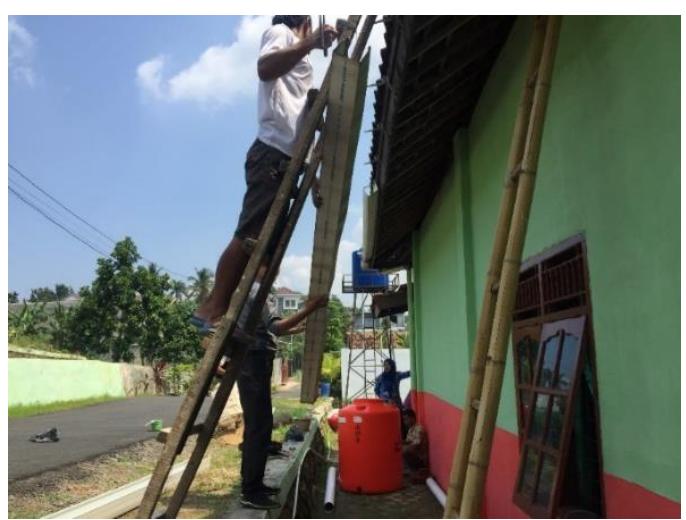

Gambar 4. Penggantuan Talang Air (Sumber :Dokumentasi Pribadi)

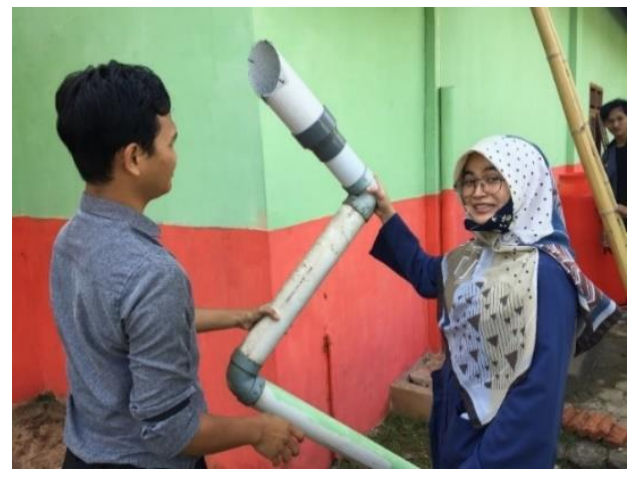

Gambar 5. Perakitan Alat Panen Hujan (Sumber :Dokumentasi Pribadi)

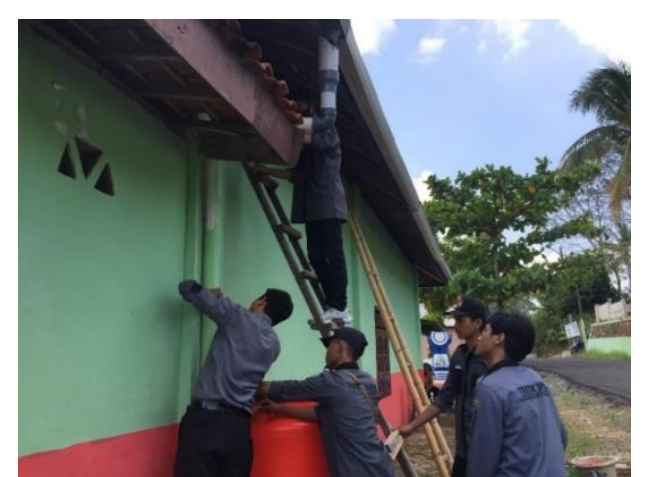

Gambar 6. Pemasangan Alat Panen Hujan (Sumber :Dokumentasi Pribadi) 


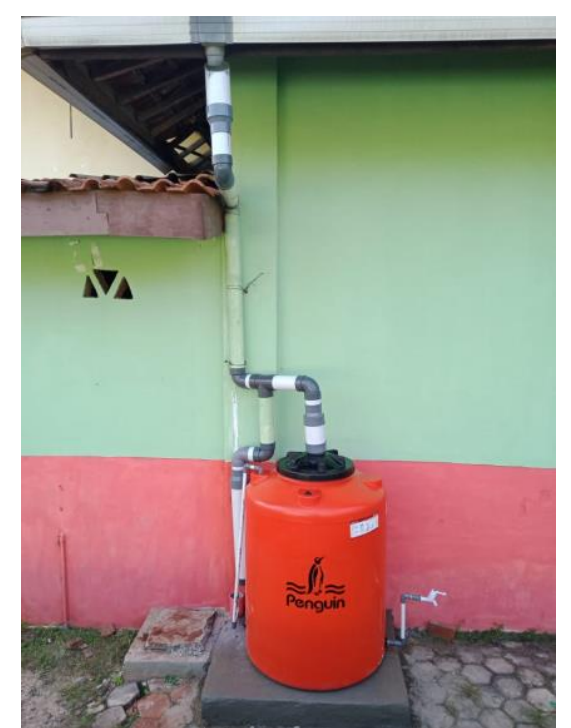

Gambar 7. Alat Panen Hujan Terpasang (Sumber :Dokumentasi Pribadi)

Dengan menerapkan kegiatan ini diharapkan kedepannya dapat mengurangi aliran run off, hal ini dapat terlihat dari daerah sasaran yang sebelumnya sering mengalami kebanjiran, dan menurut penghuni tempat tersebut, mayoritas kejadian banjir diakibatkan oleh limpasan air dengan jumlah yang besar dari atap rumah. Hal itu pula terlihat dari kondisi sasaran yang didominasi oleh penutupan bangunan. Sebagai ilustrasi dari atap seluas $1 \mathrm{~m} \times 1 \mathrm{~m}$ saja bila diestimasi curahan hujan sebesar $50 \mathrm{~mm}$ atau 0,05 $\mathrm{m}$ akan melimpaskan air sebanyak 0,05 m3 yang setara dengan 50 liter. Massa air sebesar itu bila daerahnya cukup luas dan kurang memiliki saluran pembuangan yang baik akan menimbulkan banjir. Hal ini tentunya dapat diminimalisir dengan menampung sebagian limpasan berlebih itu, air yang tertampung dapat dimanfaatkan untuk keperluan kemudian hari. Pemanfaatan air hujan secara optimal untuk menghasilkan air bersih dengan biaya yang terjangkau. Suatu kemudahan dalam pengadaan air bersih dapat berpengaruh terhadap terjaganya pola hidup yang bersih, sehat dan terjaga

\section{Perhitungan air hujan pada alat panen hujan}

$\begin{array}{ll}\text { Intensitas Hujan } & =25 \mathrm{~mm} / \mathrm{jam} \\ \text { Durasi Hujan rata-rata } & =1 \mathrm{jam} \\ \text { Luas Atap } & =9 \times 10=90 \mathrm{~m}\end{array}$

Luas atap yang memiliki talang $(20 \%)=90 x$ $0,20=18 \mathrm{~m} 2$

Volume 1 kali hujan $=0,025 \times 1 \times 22,5=$ $0,45 \mathrm{~m} 3=450$ Liter

Jika Diasumsikan 1 minggu $3 \times$ hujan $=450$ liter x $3=1350$ Liter
Kebutuhan mencuci tangan per orang $=1$ liter / 0,001 m3

Perhitungan volume air hujan dari menampung air hujan dilakukan dengan menggunakan berbagai asumsi sehingga didapatkan air yang dapat ditampung selama seminggu adalah sebanyak kurang lebih 1350 liter. Jika dalam satu hari air yang digunakan untuk mencuci tangan mencapai 60 Liter. Maka air yang tertampung mampu memenuhi kebutuhan mencuci tangan selama 22 hari. Namun faktanya air yang tertampung juga digunakan untuk menyiram tanaman sehingga air lebih cepat berkurang

Dari hasil Pengabdian yang dilakukan diketahui bahwa Kelurahan dapat menghemat penggunaan air untuk cuci tangan selama 22 hari dengan terisinya alat panen hujan, terlebih lagi jika hujan yang terjadi lebih dari 3 kali seminggu, maka air tanah disekitarnya dapat terjaga karena adanya peresapan air hujan melalui pipa yang membantu merecharge air tanah

\section{SIMPULAN DAN SARAN}

Berdasarkan kegiatan sosialisasi dan pembuatan alat panen hujan yang telah dilakukan dapat disimpulkan bahwa masyarakat antusias mengikuti sosialisasi yang dibuktikan dengan adanya partisipasi masyarakat dalam kegiatan tersebut. Alat panen hujan yang telah dibuat berfungsi dengan baik karena pada saat hujan turun air hujan masuk ke dalam alat panen hujan dan ditampung. Air hujan yang telah ditampung digunakan untuk mencuci tangan dan menyiram tanaman. Adanya tampungan dari air hujan menambah sumber air baru yang dapat dimanfaatkan untuk kegiatan sehari-hari dan menjadi suatu alternatif dalam penyediaan air bersih

\section{UCAPAN TERIMAKASIH}

Terima kasih penulis sampaikan kepada Universitas Teknokrat Indonesia yang telah memberikan dana hibah penelitian sesuai Kontrak Pengabdian Tahun Anggaran 2020Nomor : 006/UTI/LPPM/E.1.2/VII/2020 Tanggal 20 Juli 2020. Selanjutnya, terima kasih kepada ketua dan staff LPPM Universitas Teknokrat Indonesia yang telah memfasilitasi kegiatan Hibah Internal Pengabdian Kepada Masyarakat

\section{DAFTAR RUJUKAN}

Afifah, M. N. (2020). Cuci Tangan 6 Kali Sehari untuk Cegah Penularan Virus Corona. Kompas.Com.

https://health.kompas.com/read/2020/05/ 23/141000668/cuci-tangan-6-kali-sehari- 
untuk-cegah-penularan-virus-

corona?page=all

Badan Pusat Statistik. (2015). Statistik 70 Tahun Indonesia Merdeka.

Dewanto, K. (2019). Kementerian PUPR sebut 10 SPAM dalam persiapan dengan skema KPBU. Https://Www.Antaranews.Com/. https://www.antaranews.com/berita/1072 152/kementerian-pupr-sebut-10-spamdalam-persiapan-dengan-skema-kpbu

Maryono, A. (2020). Memanen Air Hujan (Rainwater Harvesting). Gajah Mada University Press.

Mugagga, F., \& Nabaasa, B. B. (2016). The centrality of water resources to the realization of Sustainable Development Goals (SDG). A review of potentials and constraints on the African continent. In International Soil and Water Conservation Research (Vol. 4, Issue 3, pp. 215-223). International Research and Training Center on Erosion and Sedimentation and China Water and Power Press. https://doi.org/10.1016/j.iswcr.2016.05.00 4

Murniningtyas, A., \& Endah, S. A. (2018). Tujuan Pembangunan Berkelanjutan di Indonesia: Vol. III (Issue 2).

Nidia, Z. (2019). Warga di Bandar Lampung Mulai Sulit Mendapatkan Air Bersih. Https://Republika.Co.Id.

https://republika.co.id/berita/pveei7382/n asional/daerah/19/07/28/pvcqu1383warga-di-bandar-lampung-mulai-sulitmendapatkan-air-bersih

Badan Perencanaan Pembangunan Nasional. (2014). PERATURAN PRESIDEN REPUBLIK INDONESIA NOMOR 2 TAHUN 2015.

Pramadiba, I. M. (2017). PBB: Jumlah Penduduk Dunia 9,8 Miliar Tahun 2050. Tempo.Co.

https://dunia.tempo.co/read/1453420/ukr aina-dorong-perundingan-damai-empatnegara-dengan-rusia

Sitorus, T. A., Faruqi, I., Simanjuntak, L. Y., Apriana, D. D., \& Mandala, D. P. A. (2010). PEMANENAN AIR HUJAN SEBAGAI SALAH SATU ALTERNATIF PENYEDIAAN AIR BERSIH DI DESA BABAKAN KABUPATEN BOGOR. In INSTITUT PERTANIAN BOGOR BOGOR. 